\title{
The Design of a Monitoring Application System for The Production of Foam Products Using the UML And Waterfall Methods
}

\author{
Henny Yulianti ${ }^{1}$, Gatot Tri Pranoto ${ }^{2}$, \\ ${ }^{1}$ Program Studi Magister Ilmu Komputer, Fakultas Teknologi Informasi, Universitas Budi Luhur \\ ${ }^{2}$ IProgram Studi Teknik Informatika, Fakultas Industri Kreatif dan Telematika, Universitas Trilogy \\ E-mail:hyulia.999@mail.com, gatot.pranoto@trilogi.ac.id
}

\begin{abstract}
The development of information technology, which is followed by a higher level of competition in the foam product industry, encouraging companies to manage their company's resources properly and to plan effective, systematic and mature activities within the company. As a company with a variety of products, the most dominant problem is in the productivity process. Production is the most important part of a manufacturing company, where in carrying out its production activities this company produces based on orders from customers (Job Orders). And the problems that often occur are planning revisions in the midst of production and changing production schedules between groups (lines), delays in production planning in terms of prioritizing planning, and still being done manually in making daily reports. By implementing monitoring, which is the supervision and control of an activity where measurements and evaluations are completed repeatedly from time to time, monitoring is carried out for the purposes of the company and to maintain ongoing management. Monitoring will provide information about the status and trend of production activities towards the company's goals. The solution to this production problem is to build a web-based foam product production monitoring system application using the Waterfall method which is integrated with UML the method used is use case diagrams, activity diagrams, sequence diagrams, class diagrams and component diagrams and software development with PHP and MySQL technology. With Black box testing, it is proven that the design of this foam production monitoring system application can assist the company's foam product production activities in fulfilling customer orders and accurate reports so that it becomes effective and efficient. in improving the productivity and performance of the company.
\end{abstract}

Keywords - Production, Monitoring, Foam, UML, Waterfall

\section{INTRODUCTION}

Good planning and systematic and mature of an activity in the company is a basic characteristic of modern industry. Because basically effective planning of materials, machines, and money will lead to margin gains where this is important in a company.

The problem that is often faced by a company is poor control or supervision in producing goods or services from the company. This causes the production of goods that are not in accordance with what was previously planned. So, the production event which the quantity or quality of production is not in accordance with the planned and applicable standards is very detrimental to the company.

PT Serim Indonesia is a company that makes flexible polyurethane foam materials. Suitable multi-functional foam for any variety of applications which is a fitting material for automobiles, electronics, household goods, shoes, furniture and construction fields. There is soundabsorbing foam, anti-bacterial, reticulated foam, sealable foam, nonyellowing foam and so on.

The problem faced by PT Serim Indonesia is that in its production department, planning revisions often occur in the midst of production and exchange of production schedules between groups (lines), delays in planning required by production in terms of prioritizing planning, and still being done manually in making daily reports. As a company with a variety of products, of course, many problems occur, one of which is in the production section. Production is the most important part of a manufacturing company, where in carrying out its production activities this company produces based on orders from customers (Job Orders).

Based on the problems discussed above, the solution is to build a web-based monitoring information system application that can be accessed online.[1]

Several studies on monitoring applications that have been carried out previously, namely, research on making aircraft health monitoring applications, architectural frameworks using the ISO-13374 standard, Condition Based Maintenance (CBM) using UML diagrams and ARINC 664 standards for transmission of health monitoring data [2]. And research on the use of the Waterfall method to develop a redesigned value-added internal monitoring framework in IT-supported organizational business processes [3]. This research uses SMILE (Self-Monitoring Interactive Learning Evaluation) application design and uses psychological health measurements based on DASS-21, the Waterfall method chosen to develop this application software [4]. Research on the role of blood hypertension monitoring systems,

From the explanations of the four previous studies, in the following the author will explain what distinguishes it from the application of previous research. The application system that will be built is a production monitoring application system using the Waterfall method which is integrated with software development implementing the UML method with a web-based system with PHP and MySQL technology to control foam products at PT. Serim Indonesian. The diagrams that will be used in the UML 
method are use case diagrams, activity diagrams, sequence diagrams, class diagrams and component diagrams where the UML diagram used is the de facto standard of modeling and analysis language in the software industry [6] and UML is an architectural description language that most widely used and ISO standard [7]. Waterfall was chosen to be used in software development because it is in accordance with the characteristics of software with high quality [8]. This application system will be able to help monitor foam production activities in the company in fulfilling orders from customers quickly and can report them accurately so that it becomes more effective and efficient in producing foam at PT. Serim Indonesian. And this can improve the company's performance and performance.

Based on this, it can be concluded that the problems and objectives and solutions to overcome them, the authors will build a web-based application system for Php and MySQL technology using the Waterfall method which is integrated with UML. This research is entitled "Designing a Monitoring Application System for Foam Product Production Using UML and Waterfall Methods"

\section{RESEARCH METHODOLOGI}

\subsection{UML Software Development Method}

In designing the software, the author uses UML (Unified Modeling Language) modeling. Designing a software system, managing complexity is one of the main reasons why you have to make a model [9], modeling helps developers to be able to focus, be able to document, capture the whole system and communicate important aspects of the system being designed [10]

To design the software, the author uses 5 diagrams in UML, namely Use case diagrams, Activity diagrams, Sequence diagrams, Class diagrams and Component Diagrams. By modeling an object-oriented application as follows:[11]

1. Use Case Diagrams

Describe the interaction between internal systems, external systems, and users. In other words, graphically describes the users who use the system, and with what technique the user relates to the system.

2. Activity Diagrams

Describe the sequential flow of the activities of a business process or Use Case. Can also be used to model the logic used by the system.

3. Sequence Diagrams

Describes how objects interact through sending messages (messages) in the execution of a use case or certain operation

4. Class Diagram

Describe the structure of system objects. Shows the classes that are components of the system, as well as the relationships between classes.

5. Component Diagram

static. This component diagram shows the organization and dependence of the system/software on pre-existing components

\subsection{PHP (Hypertext Preprocessor)}

PHP is a scripting language like HTML. In web development, HTML allows dynamic applications to be made that allow data processing and data processing. All the given syntax will be fully executed on the server while only the results are sent to the browser. Then it is a scripted language that is placed on the server and processed on the server [12].

PHP is known as a scripting language, which integrates with HTML tags, is executed on the server, and is used to create dynamic web pages such as Active Server Pages (ASP) or Java Server Pages (JSP). PHP is an open source software.

PHP programs can be activated using an Open Sourcebased PHP package, namely XAMPP. XAMPP is a PHP package developed by the Open Source community. Xammp provides Apache, MySQL, PHP and phpMyAdmin programs. The advantages of the PHP programming language from other programming languages are as follows:

1. Language PHP programming is a scripting language that does not compile in its use.

2. Web Servers PHP support can be found everywhere from Apache, IIS, Lighttpd, to Xitami with relatively easy configuration.

3. In terms of development, it is easier, because there are many developers who are ready to help in development.

4. In terms of understanding, PHP is the easiest scripting language because it has a lot of references.

5. PHP is an open-source language that can be used on various machines (Linux, Unix, Macintosh, Windows) and can be run at runtime through the console and can also run system commands.

\subsection{MySQL}

MySQL is a very popular type of database server. MySQL is a type of RDBMS (Relational Database Management System). MySQL supports the PH programming language, a structured query language, because SQL has several rules that have been standardized by an association called ANSI. MySQL is an RDBMS (Relational Database Management System) server. RDBMS is a program that allows database users to create, manage and use data in a relational model. Thus, the tables in the database have a relationship between one table and another. Some of the advantages of MySQL are:[13]

1. Fast, reliable and easy to use. MySQL is three to four times faster than commercial database servers currently available, easy to set up and does not require an expert to administer the MySQL installation.

2. Supported by multiple languages MySQL database server can give error messages in various languages such as Dutch, Portuguese, Spanish, English, French, German, and Italian.

3. Capable of creating very large tables. The maximum size of each table that can be created with MySQL is 4 GB up to a file size that can be handled by the operating system used.

4. Cheaper MySQL is open source and distributed free of charge at no cost to UNIX platforms, OS/2 and Windows Platforms

\section{RESULT AND DISCUSSION}

\subsection{Research Process}

In this study the authors used descriptive and action research methods (action research). Descriptive research is 
research that is intended to collect information about the status of an existing symptom, namely the state of symptoms according to what they were at the time the research was conducted. While the method of action (action research) is research that is used to develop new skills, new approaches, or new knowledge products and to solve problems with direct application in the actual world / field [14].

The research method used by the author is the Waterfall model method because this method takes a systematic and sequential approach. It is called a waterfall because the stages that are passed must wait for the completion of the previous stage and run sequentially. Pictures of the Waterfall model research method can be seen in Figure 1 below:[14]

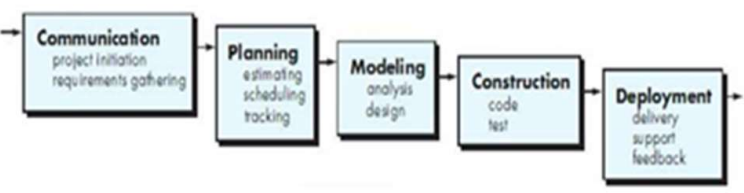

Figure 1. Waterfall Pressman (Pressman, 2015:42) [14]

1.Communication.

The first stage is that the author looks for software needs to be made, by collecting data and information at the research site, namely at PT. Indonesian Series. This process is carried out in several stages as follows:

a. Observations were made at the research site, by observing and seeing how the production process of foam products at the company was.

b. Interviews were conducted with several employees and division heads at the factory where production activities are carried out. This is done to find out, understand the needs and production processes desired by the production department at the company.

c. The author looks for various theories from various sources to support the needs of the software to be designed. And also collect the necessary data from journals, articles and the internet.

d. And analyze the problems faced with the data collected and help define the features and functions of the software according to the needs in monitoring and controlling the production of foam products and according to the conditions and wishes of the company's leadership.

2.Planning (Estimating, Scheduling, Tracking)

The next stage is the planning stage which explains the estimation of technical matters that will be made in the application of monitoring the production of foam products and their uses, conveniences and benefits that can be received by the company and the production department, especially when the monitoring application for the production of foam products is implemented. Then the resources needed to create and design the application system for monitoring the production of this foam product, the final results of the application to be produced, scheduling in making applications to be implemented, and tracking the process of working on the application system.

3. Modeling (Analysis \& Design).
This stage is the stage of designing and modeling system architecture that focuses on designing data structures, software architectures, interface displays, and program algorithms. The goal is to better understand the big picture of what will be done in designing the application for this foam product production monitoring system.

\section{Construction}

This construction stage is the process of translating the design form into a machine-readable code or form/language. After the coding is complete, testing is carried out on the system and also the code that has been created. The goal is to find errors that may occur to be corrected later.

\section{Deployment.}

The deployment stage is the stage of software implementation to the customer, periodic software maintenance, software repair, software evaluation, and software development based on the feedback provided so that the system can continue to run and develop according to its function.

\subsection{Process Design (Design)}

In making or designing application monitoring software for the production of foam products, the author uses the UML model method [9][10] which consists of 5 diagrams in UML, namely Use case diagrams, Activity diagrams, Sequence diagrams, Class diagrams and Component Diagrams [11]. ].

1. Use Case Diagrams.

This research is modeling that will be used to describe the functional requirements of the software that is built by using use case diagrams. The use case diagram consists of 4 (four) actors, namely general admin, warehouse, head of production and marketing. It can be seen in Figure 2 as follows:

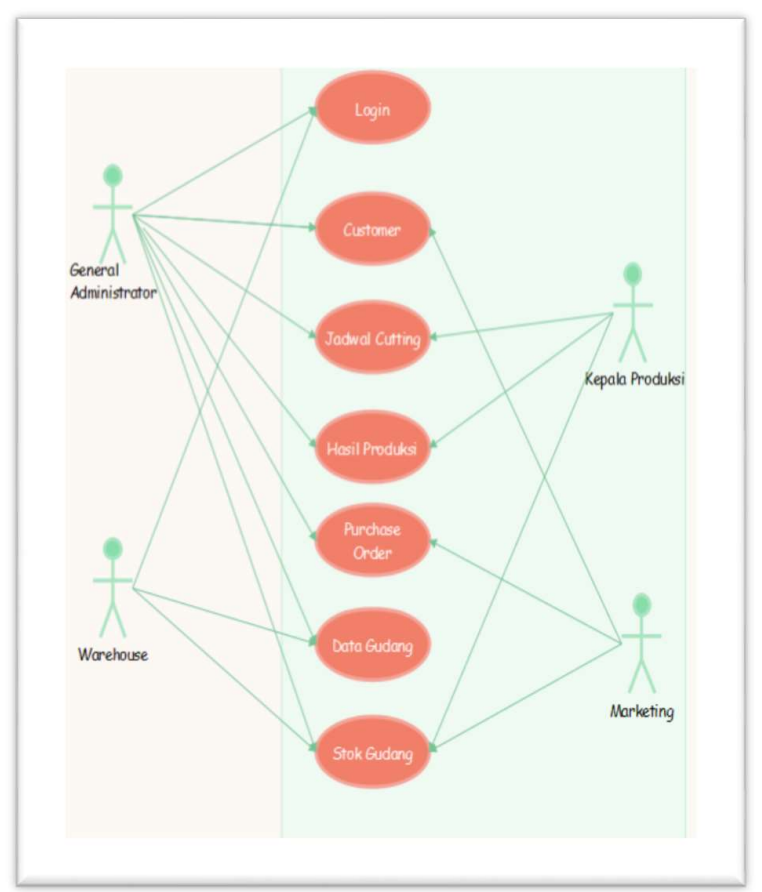


Figure 2. Use Case Diagram

\section{Activity Diagrams}

Activity diagrams are used to describe a series of flow of activities, used to describe activities that are formed in one operation so that it can also be used for other activities. Figure 3 below illustrates the Activity diagram process for the admin process to process customer data, such as adding new data, changing, and deleting customer data.

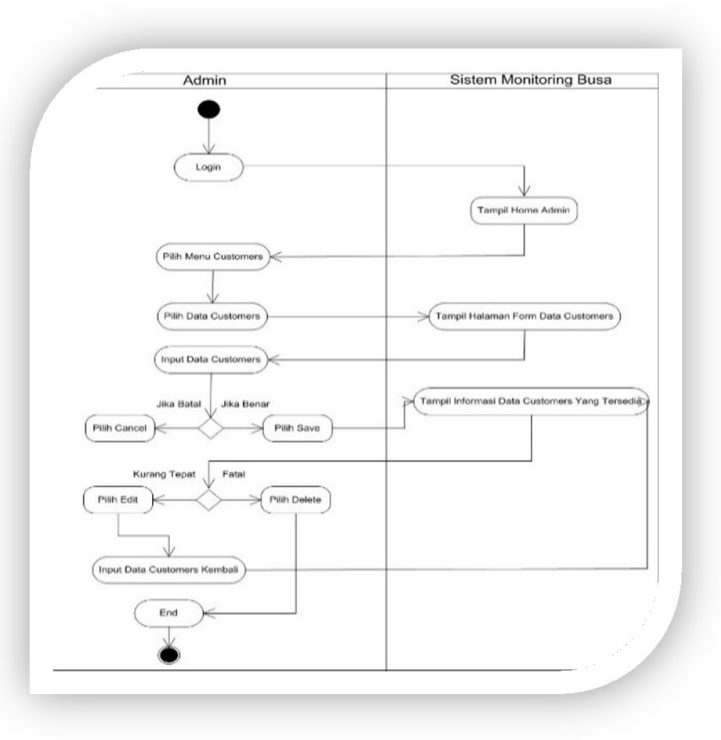

Figure 3. Activity Diagram of the Customer Process

The activity diagram in Figure 4 illustrates the purchase order process, where the admin enters Purchase order data into the system. Starting from the login process by entering the username and password, if incorrect, the user will get an error message from the system, but if it is correct then the user can enter the main page, then the user selects the purchase order data menu and selects the submenu.

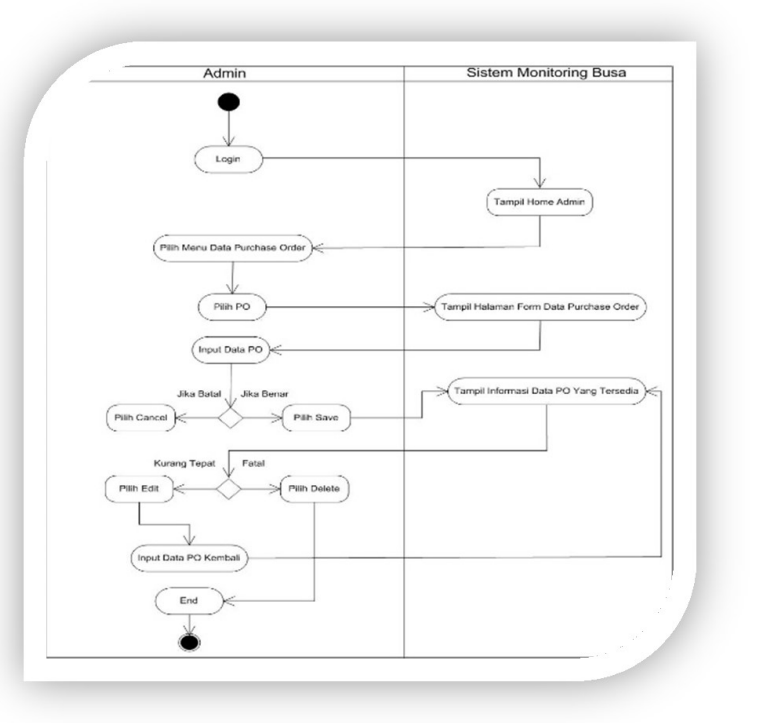

Figure 4. Activity Diagram of the Purchase Order Process

In this Activity diagram, it describes the admin process for processing Production Results data, such as adding new data, changing, and deleting production data. An overview of the Activity diagram of the production data processes as

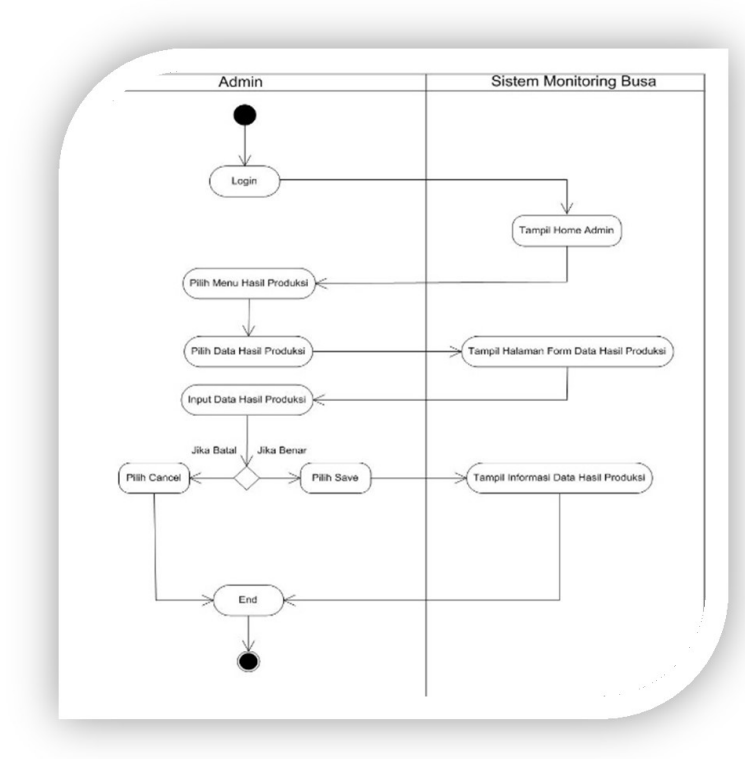

shown in Figure 5 below;

Figure 5. Activity Diagram of Production Results

\section{Sequence Diagram}

Sequence diagrams used to describe a scenario or a series of steps taken in response to an event to produce a certain output, this diagram shows a number of examples of objects and messages placed between objects in a use case diagram.

Sequence Diagram of Goods Data, which describes the flow of goods data processing which is input data starting from logging into the main menu to entering the goods data form to carry out the goods data input process to the process of adding, updating or deleting the goods data. The following is Figure 6, which shows a sequence diagram of the goods data;

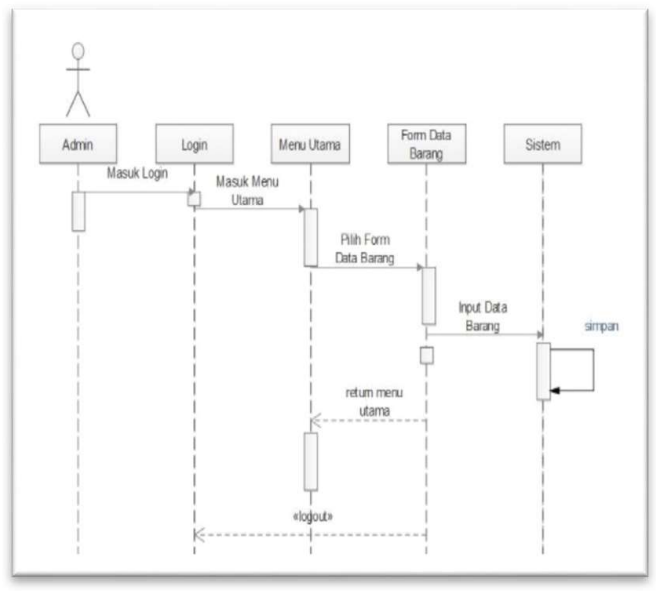

Figure 6. Sequence Diagram of Goods Data

Sequence Diagram of Stock Goods Data, which describes the flow of stock data processing which is input data starting from logging into the main menu to entering the stock item data form to process stock data input to the 
process for adding, updating or deleting the stock data. The following is Figure 7, which shows a sequence diagram for

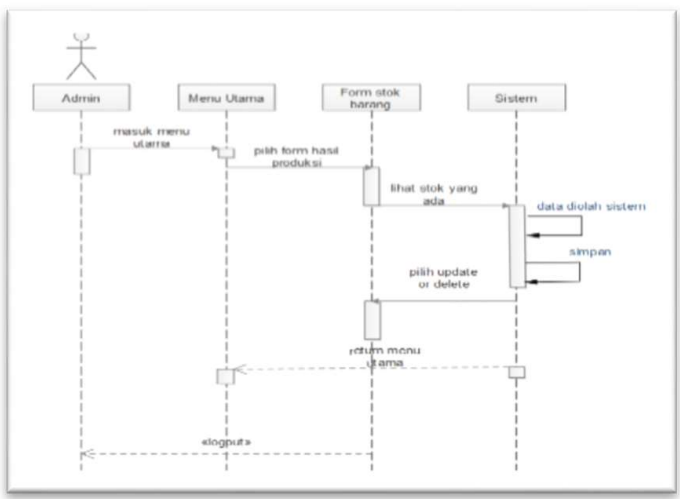

the stock of goods;

Figure 7. Sequence Diagram of Stock Items

The customer data sequence diagram describes the customer data processing flow which is input data starting from logging into the main menu to entering the customer data form to process customer data input to the process of adding, updating or deleting customer data. The following is Figure 8, which shows the customer sequence diagram;

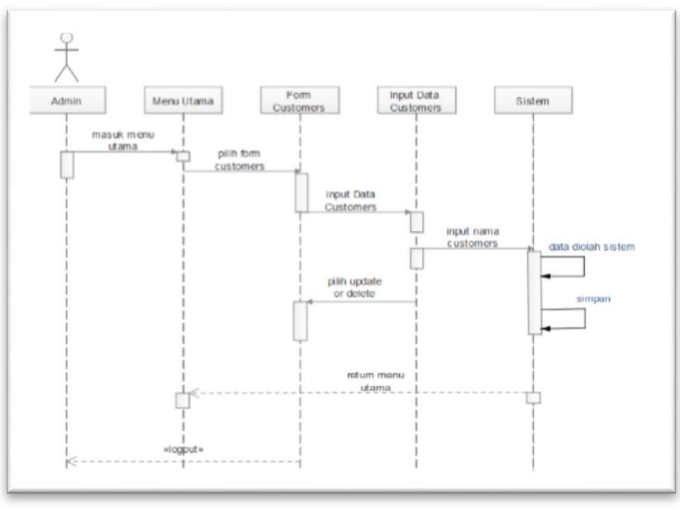

Figure 8. Customer Sequence Diagram

Sequence diagram of the production data describes the process flow of production data processing which is input data starting from logging into the main menu to entering the production data form to carry out the production data input process to the process of adding or deleting the production data. The following is Figure 9, which shows a sequence diagram of the production results;

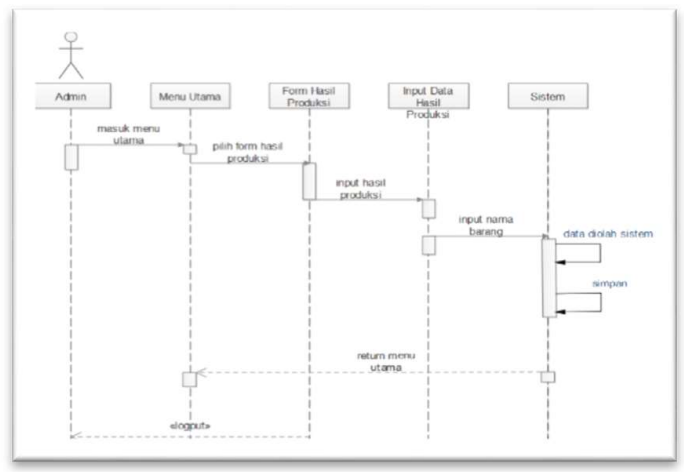

Figure 9. Sequence Diagram of Production Results

\section{Class Diagrams}

Class Diagram describes the structure of the system in terms of defining the classes that will be created to build a system. Class Diagram is a type of static structure diagram in the Unified Modeling Language (UML) that describes the structure of the system by showing the system classes, their attributes, methods, and the relationships between objects. Figure 10 below, illustrates the static structure of classes in the system foam product production monitoring application

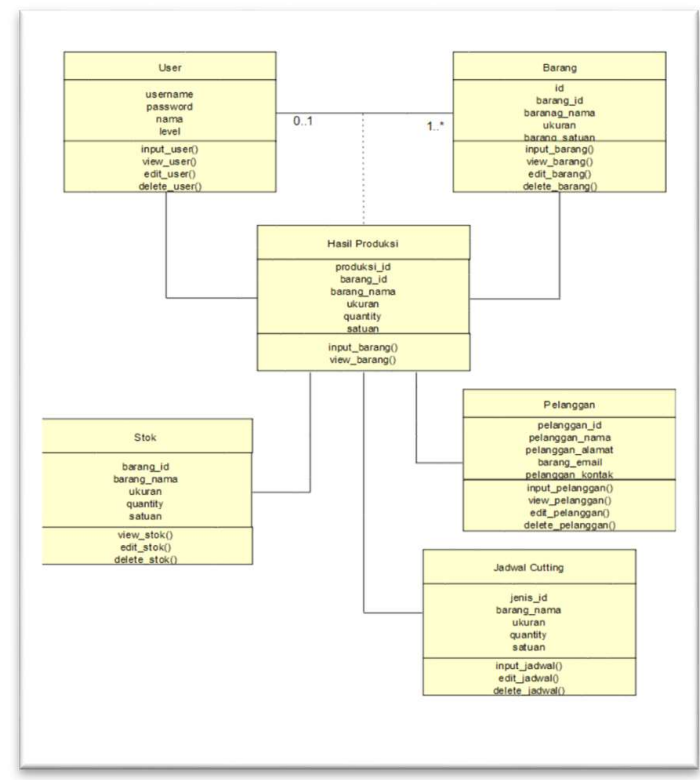

Figure 10. Class Diagram System

\section{Component Diagrams}

Component diagrams are made to illustrate the structure and dependencies between a collection of components in a system. Figure 11 below is a component diagram of a monitoring application system for foam product production;

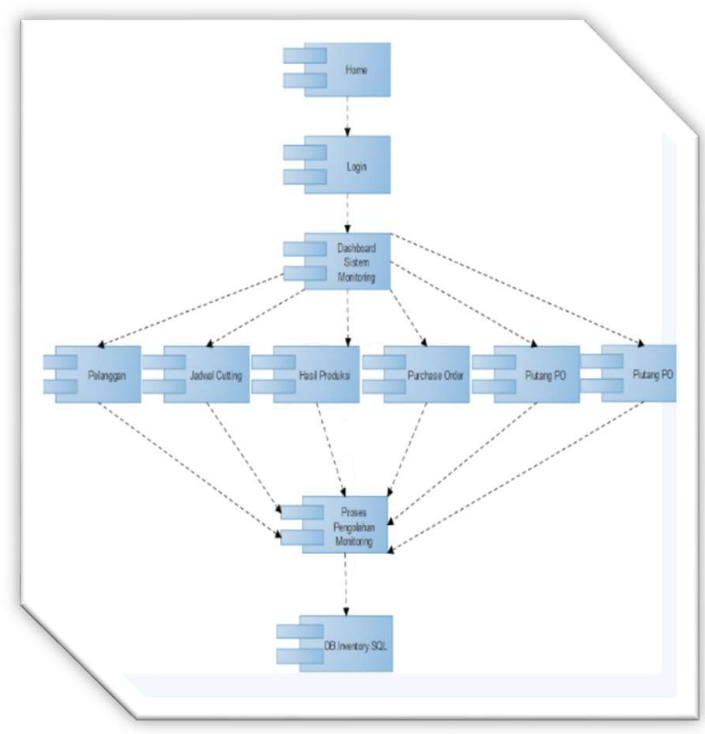

Figure 11. Component Diagram

JISA (Journal of Informatics and Science) (e-ISSN: 2614-8404) is published by Informatics Engineering Study Program, Trilogy University under Creative Commons Attribution-ShareAlike 4.0 International License. 


\subsection{Application Design Results}

After going through the analysis process and explaining the steps in designing a Web-Based Foam Production Monitoring Information System at PT. Serim Indonesia, the following display of the information system that has been designed:

a. Login Page

The login page is the page used by all system users to enter the main page. In this initial step, the application displays the main page form where the main page form contains information about the initial display / front page

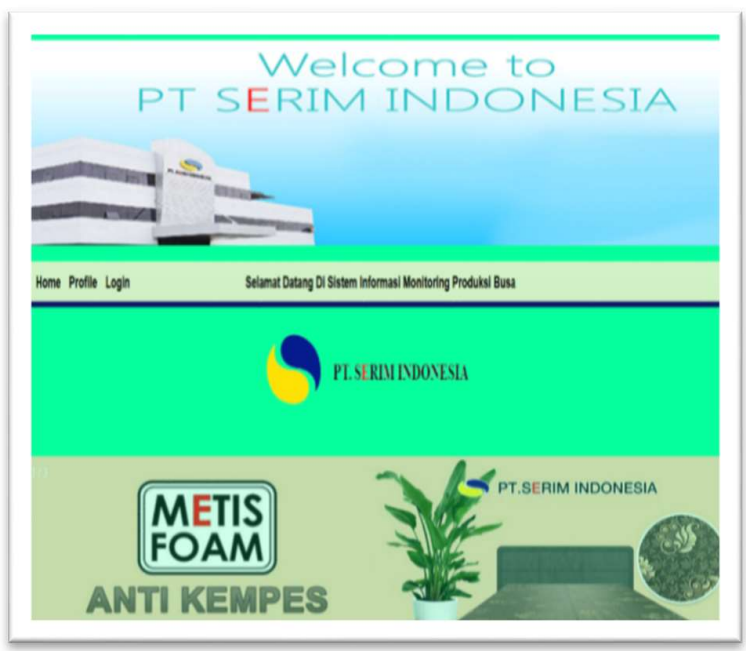

Figure 12. Login Page Display

\section{b. Product Page}

Product page is the main page after the profile page form, there is a product menu where the menu displays all the contents of the products in PT. Indonesian Series.

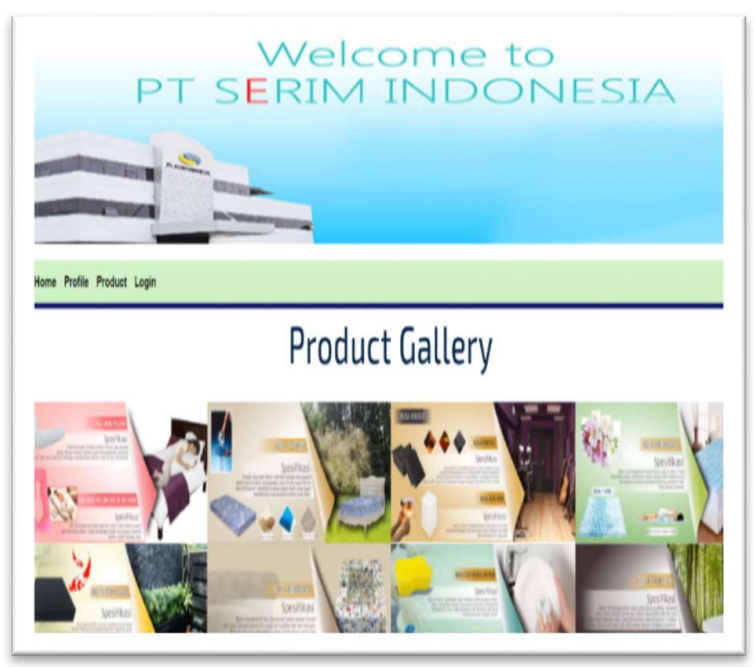

Figure 13. Product Page Display

c. Main Menu Page

The Main Menu will appear after logging in as a user. The display of this form shows what forms can be accessed by the user.

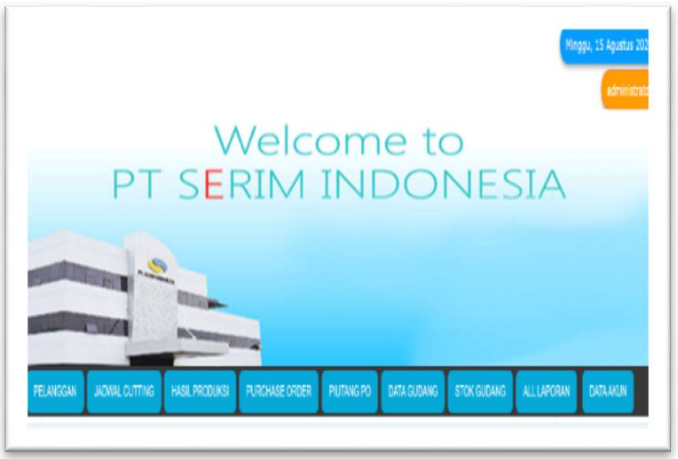

Figure 14. Main Menu Page Display

d. Customer Data Menu Display

This Customer Menu contains all transaction activities consisting of several parts such as: No, Customer Name, Address, City, Email, and Contact

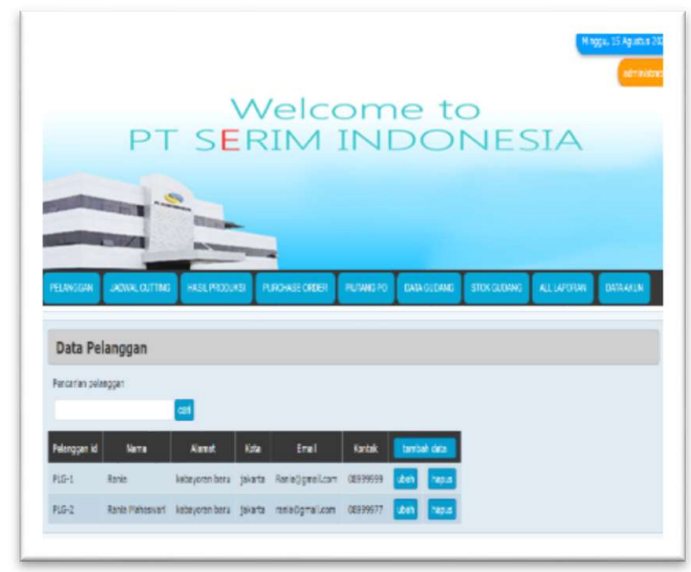

Figure 15. Display of Customer Data Menu

e. Production Cutting Schedule Menu Display

The Production Cutting Schedule Menu contains all transaction activities consisting of several parts such as: No, Customer Name, Item Name, Item Size, Quantity, Part, and Description

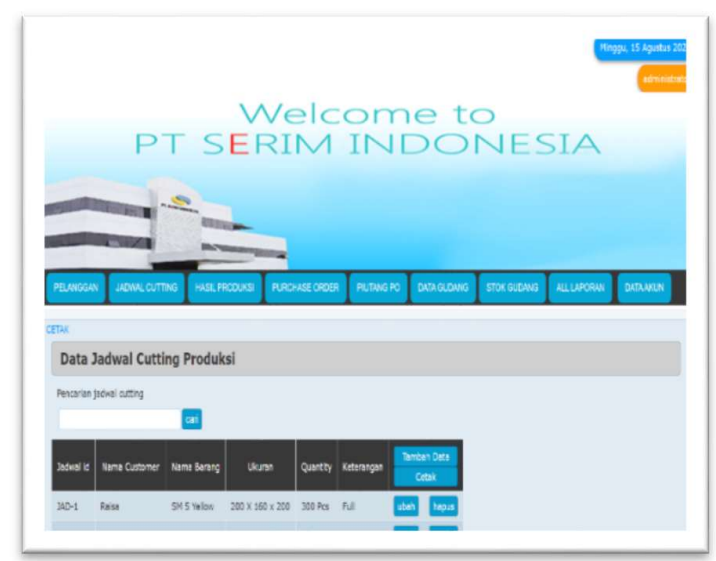

Figure 16. Production Cutting Schedule Menu Display

f. Purchase Order Menu Display

This Purchase Order Menu contains all transaction 
activities consisting of several parts such as: No, No Note, Transaction date, customer name, Amount paid, receivable and due date

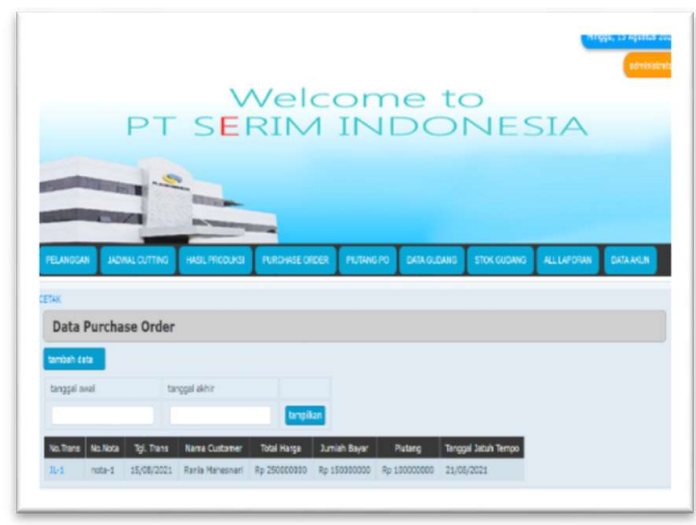

Figure 17. Display of Purchase Order Menu

g. Warehouse Stock Menu Display

The Warehouse Stock Menu contains all transaction activities consisting of several parts such as: No, Item Name, category, Quantity and unit.

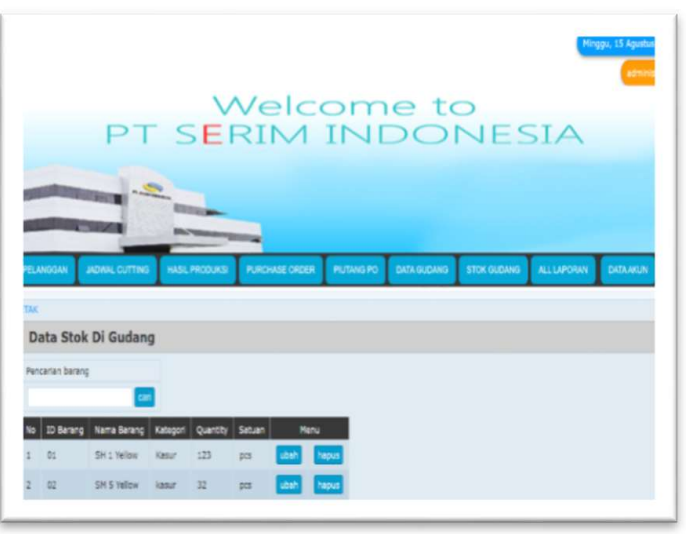

Figure 13. Warehouse Stock Menu Display

h. PO Receivable Menu Display

In the Menu Display this Po Receivable Data contains transaction activities to make payments for the remaining POs that have been previously paid which consist of several parts such as: No, Transaction No, Date, Customer Name, Initial Receivable, Remaining Receivables and Information

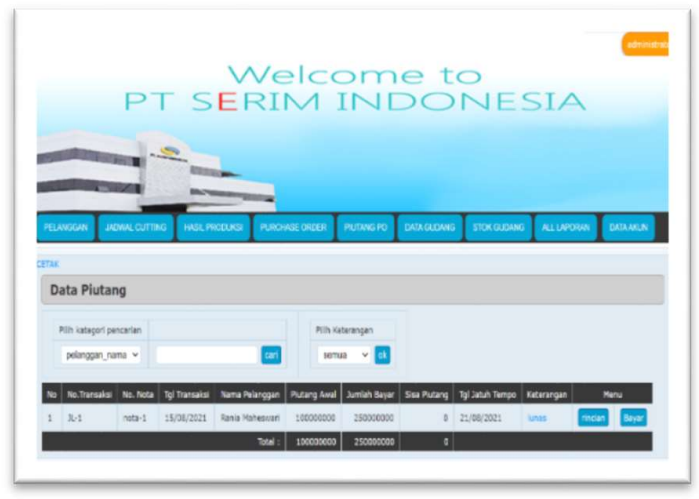

Figure 14. Report Menu Page Display
I. Report Print View

In the print view, this report contains the process of report data to be printed.

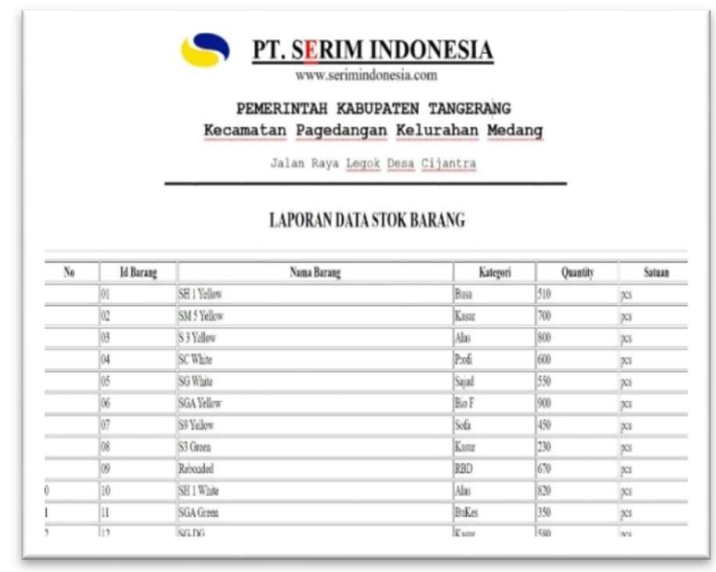

Figure 15. Print Report Page Display

\subsection{Black Box Test}

At the Black box testing stage of the online Foam Product Production Monitoring System application, testing is carried out by running all the functions and features available from this application and then seeing whether the results of these functions are as expected, [15]

Testing is carried out, using the assumption of not knowing the internal structure of the program (black box). Concentrate on finding conditions where the program does not run according to specifications (functional) using specifications for test data [16]

This test is carried out after the system is made by testing all the existing buttons. This test ensures whether the process carried out produces output that is appropriate or not in accordance with the design.[17]

Table 1. BLACK BOX TEST

\begin{tabular}{|c|c|c|c|}
\hline No & $\begin{array}{l}\text { Things } \\
\text { to Test }\end{array}$ & Results obtained & Results \\
\hline 1 & $\begin{array}{l}\text { Page } \\
\text { Main }\end{array}$ & $\begin{array}{l}\text { a. Go back to the main page. } \\
\text { b. Go to the profile page. } \\
\text { c. Go to the product page. } \\
\text { d. Go to the login page. }\end{array}$ & $\begin{array}{c}\text { In } \\
\text { accorda } \\
\text { nce }\end{array}$ \\
\hline 2 & $\begin{array}{l}\text { Menu } \\
\text { Main }\end{array}$ & $\begin{array}{l}\text { a. Go to the main menu page. } \\
\text { b. Go to customer data page } \\
\text { c. Go to the production cutting } \\
\text { schedule page. } \\
\text { d. Go to the production page. } \\
\text { e. Go to the purchase order page. } \\
\text { f. Go to the item data page. } \\
\text { g. Go to stock data page } \\
\text { h. Go to accounts receivable page. } \\
\text { i. Go to Report Page. } \\
\text { j. Go to the user data page. } \\
\text { k. Log out of the system. }\end{array}$ & $\begin{array}{c}\text { In } \\
\text { accorda } \\
\text { nce }\end{array}$ \\
\hline 3 & $\begin{array}{l}\text { Productio } \\
\text { n Cutting } \\
\text { Schedule } \\
\text { Form }\end{array}$ & $\begin{array}{l}\text { a. Displays additional production } \\
\text { cutting schedule data. } \\
\text { b. Displays in detail the available } \\
\text { cutting schedule. } \\
\text { c. Displays changes to the } \\
\text { production cutting schedule } \\
\text { data process. } \\
\text { d. Displaying deletions in } \\
\text { production cutting schedule } \\
\text { data }\end{array}$ & $\begin{array}{c}\text { In } \\
\text { accorda } \\
\text { nce }\end{array}$ \\
\hline
\end{tabular}




\begin{tabular}{|c|c|c|c|}
\hline 4 & $\begin{array}{l}\text { Productio } \\
\text { n Result } \\
\text { Form }\end{array}$ & $\begin{array}{l}\text { a. Displays the addition of } \\
\text { production data. } \\
\text { b. Displays print for production } \\
\text { results. } \\
\text { c. Displays changes in the } \\
\text { production data process. } \\
\text { d. Displays deletions on } \\
\text { production data. }\end{array}$ & $\begin{array}{l}\text { In } \\
\text { accorda } \\
\text { nce }\end{array}$ \\
\hline 5 & $\begin{array}{l}\text { Purchase } \\
\text { Order } \\
\text { Form }\end{array}$ & $\begin{array}{l}\text { a. Displays additions to the } \\
\text { purchase order data. } \\
\text { b. Display print on purchase order } \\
\text { data } \\
\text { c. Displays changes to the } \\
\text { purchase order data process. } \\
\text { d. Displaying deletions on } \\
\text { purchase order data }\end{array}$ & $\begin{array}{l}\text { In } \\
\text { accorda } \\
\text { nce }\end{array}$ \\
\hline 6 & $\begin{array}{l}\text { Customer } \\
\text { Data } \\
\text { Form }\end{array}$ & $\begin{array}{l}\text { a. Displays additions to customer } \\
\text { data. } \\
\text { b. Displays changes to the } \\
\text { customer data process. } \\
\text { c. Displays deletion on customer } \\
\text { data. }\end{array}$ & $\begin{array}{c}\text { In } \\
\text { accorda } \\
\text { nce }\end{array}$ \\
\hline 7 & $\begin{array}{l}\text { Item Data } \\
\text { Form }\end{array}$ & $\begin{array}{l}\text { a. Displays additions to item data. } \\
\text { b. Displays changes to the process } \\
\text { of goods data. } \\
\text { c. Displays deletion on item data. }\end{array}$ & $\begin{array}{c}\text { In } \\
\text { accorda } \\
\text { nce }\end{array}$ \\
\hline 8 & $\begin{array}{l}\text { Stock } \\
\text { Data } \\
\text { Form }\end{array}$ & $\begin{array}{l}\text { a. Displays additions to stock } \\
\text { data. } \\
\text { b. Displays changes to the stock } \\
\text { data process. } \\
\text { c. Displays deletions on stock } \\
\text { data. }\end{array}$ & $\begin{array}{c}\text { In } \\
\text { accorda } \\
\text { nce }\end{array}$ \\
\hline 9 & $\begin{array}{l}\text { From All } \\
\text { Report }\end{array}$ & $\begin{array}{l}\text { a. Displays the Cutting Schedule } \\
\text { Report. } \\
\text { b. Displaying Production Results } \\
\text { Report. } \\
\text { c. Displays Purchase Order } \\
\text { Report. } \\
\text { d. Displaying PO Accounts } \\
\text { Receivable Report. } \\
\text { e. Displays the Cutting Schedule } \\
\text { Report. }\end{array}$ & $\begin{array}{c}\text { In } \\
\text { accorda } \\
\text { nce }\end{array}$ \\
\hline 10 & $\begin{array}{l}\text { Account } \\
\text { Data } \\
\text { Form }\end{array}$ & $\begin{array}{l}\text { a. Displays admin data storage } \\
\text { When making changes to user } \\
\text { data. } \\
\text { b. Displays reset on user data } \\
\text { When making changes to user } \\
\text { data. } \\
\text { c. Displays cancel on user data. }\end{array}$ & $\begin{array}{c}\text { In } \\
\text { accorda } \\
\text { nce }\end{array}$ \\
\hline
\end{tabular}

- Based on the Black Box testing, the login and menus carried out in this application are to check whether the functionality of the menu and login form has been running well and testing for user-accessible menus in the foam production monitoring application is functioning properly.

\section{CONCLUSION}

Based on the results of research, design and testing that has been carried out on the application of monitoring the production of foam products PT. Serim Indonesia with the stages of the process that has been carried out starting from planning, analysis, design, coding, implementation and testing. Black box, the authors draw the following conclusions:

1. With advances in information technology today, the development of a Web-based Foam Product Production Monitoring System using the Waterfall method which is integrated with the UML software development method is going well. And it is proven that applications designed with PHP and MySQL technology can be compatible with both online.

2. The results of the Blackbox test, indicate that all functionality in the application has been running well in accordance with online planning and design. Where it is proven that the Foam Product Production Monitoring Application that has been designed can control foam product production activities in fulfilling customer orders quickly and with accurate reports. So that it can increase the production activities of foam products and the company's performance.

\section{REFERENCES}

[1] X. Zhang, B. Zheng and L. Pan, "Using Virtual Reality Technology to Visualize Management of College Assets in the Internet of Things Environment," in IEEE Access, vol. 8, pp. 157089157102,2020,doi:10.1109/ACCESS.2020.3019836.

[2] AK Jha, S. Nayak and NK Veerabhadrappa, "An Architecture for Performing Real Time Integrated Health Monitoring of Aircraft Systems Using Avionics Big Data," 2nd International Conference on Computational Systems and Information Technology for Sustainable Solutions (CSITSS), 2017, pp. 1-5, Doi:10.1109/CSITSS.2017.8447679

[3] R. Van Hillo and H. Weigand, "Continuous Auditing \& Continuous Monitoring: Continuous Value?" IEEE Tenth International Conference on Research Challenges in Information Science (RCIS), 2016, pp. 1-11, Doi:10.109/RCIS.2016.7549279.

[4] WA Syafei et al., "SMILE (Self-Monitoring Interactive Learning Evaluation) for Indonesian University Students," International Biomedical Instrumentation and Technology Conference (IBITeC), 2019, pp.12-16, Doi: 10.1109/IBITeC465 97.2019 .9091726

[5] AV Demidov, DV Papshev and LY Krivonogov, "Principles of Construction, Structure and Features of the ECG and Blood Pressure Monitoring System," 2020 Moscow Workshop on Electronic and Networking Technologies (MWENT), 2020, pp. 15, Doi:10.109/MWENT47943.2020.9067390.

[6] Y. Yang, W. Ke, J. Yang and X. Li, "Integrating UML With Service Refinement for Requirements Modeling and Analysis," in IEEE Access, vol. 7, pp. 
11599-11612, 2019, Doi: 10.1109/ACCESS.2019. 2892082.

[7] J. MaIm, F. Ciccozzi, J. Gustafsson, B. Lisper and J. Skoog, "Static Flow Analysis of the Action Language for Foundational UML," IEEE 23rd International Conference on Emerging Technologies \& Factory Automation (ETFA), 2018, pp. 161-168, Doi:10.1109/ETFA.2018.8502620.

[8] S. Balaji and MA Obaidy, "Project characteristics used for methodology selection to develop the software project," International Conference on Electrical, Electronics, and Optimization Techniques (ICEEOT), 2016, pp. 3570-3573, Doi: 10.109/ICEEOT.2016.7755370.

[9] A. Hafeez Khan, S. Hyder Abbas Musavi, A. Rehman and A. Shaikh. "Ontology-Based Finite Satisfiability of UML Class Model", IEEE Access, vol.6, pp.3040-3050. Doi:10.1109/ACCESS.2017 2786781.

[10] Samuel Szoniecky, "Graphical Specifications for Modeling Existence", in Ecosystems Knowledge: Modeling and Analysis Method for Information and Communication, Wiley, pp.89-115.Doi:10. 1002/978 1119388777.ch4.

[11] L. Ordinez, G. Eggly, M. Micheletto and R. Santos, "Using UML for Learning How to Design and Model Cyber-Physical Systems". IEEE Revista Iberoamericana de Tecnologias del Aprendizaje (RITA), vol.15, no.1, pp.50-60. Doi:10. 1109/ RITA. 2020.2978416 .

[12] SI Adam and S. Andolo, "A New PHP Web Application Development Framework Based on MVC Architectural Pattern and Ajax Technology". 1st International Conference on Cybernetics and Intelligent Systems (ICORIS), pp. 45-50, Doi:10.1109/ ICORIS. 2019.8874912.

[13] MM Eyada, W. Saber, MM El Genidy and F. Amer, "Performance Evaluation of IoT Data Management Using MongoDB Versus MySQL Databases in Different Cloud Environments". IEEE Access, vol.8,
pp.110656-110668.Doi:10.1109/ACCESS.2020. 3002164.

[14] Pressman R, S, "Software Engineering", Publisher Andi Yogyakarta, (2015) Page 42.

[15] TH Chang, J. Larson, LT Watson and TCH Lux, "Managing Computationally Expensive Blackbox Multiobjective Optimization Problems with Libensemble", Spring Simulation Conference (SpringSim), (2020) pp.1-12. Doi:10.22360/ SpringSim. 2020.HPC.001.

[16] J.Pan, "Blackbox Trojanising of Deep Learning Models: Using Non-Intrusive Network Structure and Binary Alterations", IEEE Region 10 Conference (TENCON), (2020), pp.891-896. Doi:10.1109 /TENCON50793.2020.9293933.

[17] R Guidotti, A Monneale, F Giannotti, D Pedreschi, S Ruggieri F Turini, (2019)," Factual and Counterfactual Explanations for Black Box Decision Making”, IEEE Intelligent Systems, Vol 34, No6, pp,14-23. Doi:10.1109/MIS.2019.2957223 